特別支援学校の教員の介助犬認知度に関する 調查

田辺 冬華 ${ }^{1)}$ 、山口 歩 ${ }^{1)}$ 、遠藤 大輔 ${ }^{1)}$ 、水上 言 1 )、高柳 友子 1 )、 後藤 優花 ${ }^{1)}$ 、水谷 悠美 ${ }^{1)}$ 、野口 裕美 ${ }^{2)}$ 、野下 朋美 3 )

1）社会福祉法人日本介助犬協会

2）学校法人・専門学校名古屋医專

3）社会医療法人総合大雄会病院

\title{
A Survey on Awareness of Service Dogs among Teachers of Schools for Physically Disabled Children
}

\author{
Fuyuka Tanabe ${ }^{1)}$, Ayumi Yamaguchi ${ }^{1)}$, Daisuke Endo ${ }^{1)}$, Koto Mizugami ${ }^{1)}$, Tomoko Takayanagi ${ }^{1)}$, \\ Yuka Goto $^{1)}$, Yuumi Mizutani ${ }^{1)}$, Hiromi Noguchi ${ }^{2}$, Tomomi Noshita $^{3)}$ \\ 1) Social Welfare Corporation, Japan Service Dog Association \\ 2) Educational Foundation, Technical School, Nagoya Medical College \\ 3) Social Medical Corporation, Daiyukai Hospital
}

抄 録

全国で活動している介助犬は 74 頭（2015年 8 月現在）と未だ十分に普及しているとは言えず、理由の一 つとして障害当事者の認知度の低さが考元られる。より若年者に自立や社会参加の手段の一つとして介助犬 という選択肢を提供することで未来の介助犬使用者の発掘にもつながるのではないかと考元、将来介助犬使 用者になり得る生徒がいる特別支援学校（肢体不自由）の教員を対象に介助犬の認知度についてアンケート 調査した。結果、メディア等により介助犬は聞いたことはあるが正しい理解や具体的なイメージを持ってい ない教員が多いことが明らかになった。今後の啓発方法としては、介助犬を正しく知って貴えるように、介 助犬総合訓練センターでのイベントの開催に限らず、特別支援学校向けの資料の作成・配布、特別支援学校 へ出向いてのデモンストレーションや使用者による講演といった自分の目で見たり聞いたりできる機会の提 供が必要であると考えられた。

キーワード : 介助犬、特別支援学校、教員、啓発活動、デモンストレーション 


\section{Abstract}

Currently 74 service dogs are working in Japan (as of Aug. 1, 2015). This number is far less than that of potential users. One of the reasons for the discrepancy is the poor awareness about service dogs among potential physically disabled users. Educating the young physically disabled about service dogs as one of the helps for independence and social participation may lead to an increase in future service dog use. In this study, therefore, we conducted a survey on the awareness of service dogs among the teachers of schools for physically disabled children - possible future service dog users. The result showed that most of them lacked correct understanding and specific image of service dogs though they knew the presence of the dogs through media coverage. In addition to our current promotion method of hosting events at the Service Dog Training and Rehabilitation Center in Aichi Prefecture, to improve our promotion methods, distribution of the brochures and the demonstration and the lecture by service dog users held at the schools should be provided.

Keywords: service dog, schools for physically disabled children, promotion activity, demonstration 


\section{I．序論}

盲導犬、介助犬及び聴導犬からなる身体障害者補 助犬は、身体障害者の自立及び社会参加の促進に寄 与する「生きた補装具」であると考えられる。

介助犬を使用する障害者は肢体不自由者であり、 2006年の厚生労働省の身体障害者調査では 176 万人 を数える ${ }^{11}$ 。その内、介助犬の必要性が考元られる 身体障害者障害程度等級の 1 級と 2 級即ち、上下 肢、体幹の機能の著しい障害を示す障害者数は 1 級 44 万 9000 人、 2 級が 31 万 2000 人を示し、総計 76 万 1000 人に達する ${ }^{1)}$ 。この全ての人が介助犬使用適応 者ではないが、介助犬の使用によって自立、社会参 加、社会復帰が期待できると考えられる障害者は多 (2)。それに対し、全国で活動している介助犬は74 頭 ${ }^{3)}$ であり、未だ十分に普及しているとは言えない。 介助犬という存在自体を知らずに手を挙げられない 障害者、知っていても自分の障害の程度では持てな いのではないかと考えている障害者が多いなど、介 助犬が普及していかない原因の一つとして障害当事 者の認知度の低さや正しい理解の不足が考えら れる。

介助犬は障害者の自己管理能力と経済効果、さら に介助犬の経済性の観点から年齢制限が必要とな り、18歳以上とするのが一般的であるが2)、介助犬 使用者となり得る障害当事者（成人）に対する介助 犬への興味や期待、不安について、大林らは全国自 立生活センターの会員102名を対象とした意識調査 を1999年に実施し、介助犬を知っている障害者は 95\%、テレビで知った回答者が $75 \%$ 。回答した障 害者の 4 分の 3 が介助犬に興味があり、4 分の 1 が 介助犬をほしがっていることを報告している4)。

近年障害の重度化・重複化に伴い、特別支援学校 （肢体不自由）においては 7 割を超える高い重複障 害学級在籍者率が報告されている5 る中で、特別支援学校の生徒における介助犬の有効 性の把握、それに伴う啓発活動の有効性や方法の検 討、さらには、より若年者に自立や社会参加の手段 の一つとして介助犬という選択肢を提供すること で、将来の介助犬使用につながるのではないかと考 え、生徒や保護者に対して強い発信力を持つ特別支 援学校（肢体不自由）の教員を対象にアンケート調 査を行うこととした。

\section{II. 方法}

2014年 1 月 14 日〜 2月14日にかけて、三重県の 特別支援学校（肢体不自由）の教員 120 名を対象と して郵送によるアンケート調査を実施した。アン ケートは回答者個人が特定されないよう無記名式と した。調査内容としては、(1)回答者属性(2)介助犬に ついて(3)生徒について(4)授業についての 4 分野 15 項目において選択及び自由記述による質問を行った (表 1 )。

\section{III. 結果}

\section{1．回答者属性}

本調査は、120名中 50 名（男性 20 名、女性 30 名） から回答を得た。年代は 40～50代が $57 \% 、 20 ３ 0$ 代 $41 \%$ 、60代は $2 \%$ であった。教員歴は 21 年以上 が $37 \%$ と最も多く、次いで 1 〜 10 年が $35 \% 、 11 〜$ 21 年が $22 \% 、 1$ 年未満は $6 \%$ であった。

\section{2. 介助犬に関する理解}

介助犬の認知度としては「知っている」「少し 知っている」が共に $42 \%$ 、よく知っている」 $4 \%$ 、 「聞いたことがある」12\%で、「知らない」との回答 はなかった（図 1 )。

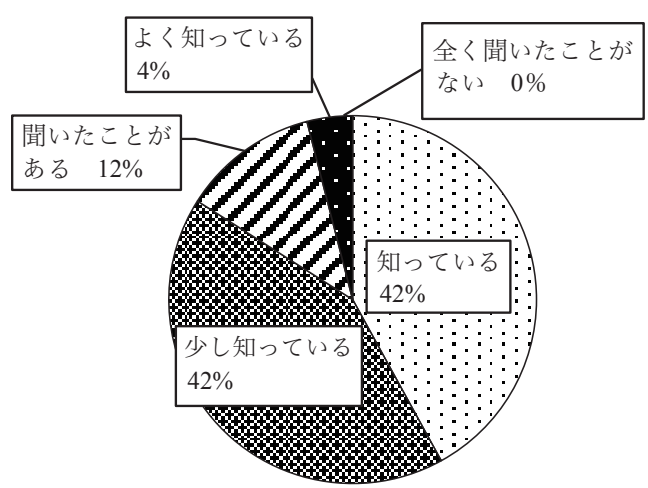

図 1 : 介助犬の認知度

介助犬を知ったきっかけは、「テレビ」が $84 \%$ と 最も多く、次いで「新聞」が52\%、「本・雑誌」 42\%、「インターネット」と「介助犬に関するイベ ントに参加した」が共に $4 \%$ 、「その他（DVD、知 人の話）」が $4 \%$ という結果であった（図 2 ）。 


\section{表 1 : アンケートの質問項目一覧}

「肢体不自由児特别支援学校の教員に詨寸る介助犬に關する調查」

このアンケートは、肢体不自由者の自立や社会参加のお手伝いをする「介助犬」の認知度や理解度、 肢体不自由児特別支援学校の児童生徒における介助犬の有效性の把握、を水に伴う啓発活動の有効 性や方法の考察を目的に実施致します。

以下の啠問に対して該当するもの在選び、番号に○をつけてください。また、枠がある場合には 自由に記述してください。

\section{【回答者属性】}

、回答される方ご自身についてお答えください

性别: 1) 男 2) 女

年齢：1）20代 2) 30 代 $3 ４ 00$ 代 4) 50 代

教員歴：1） 1 年未満 $\quad 2 ） 1 \sim 5$ 年 $3 ） 6 \sim 10$ 年 $4 ） 11 \sim 15$ 年 5$) 16 \sim 20$ 年

6) $21 \sim 25$ 年 7) 26 年以上

【介助犬について】

2. 介助犬にっいて知っていますか?

1）良く知っている 2）知っている $3 ）$ 少し知っている 4）閏いたことがある

5) 全く知らない

1）〜4）と答えた方は、どの上うな方法で知りましたか?（複数回答可）

1) テレピ

2) 新聞

3) 本、雑誌

4) インターネット

5）介助犬に關するイベントに参加した

6) その他 (

\section{3、介助犬にっいてより詳しく知りたいと思いますか?}

1)はい 2) いいえ

1）と答えた方は、具体的にどのような方法で知りたいですか?（複数回答可）

1）デモンストレーション（抒仕事紹介）を実際に見る

2) 介助犬育成施設の見学に行く

3) 犬使用者の扩話を聞く

4) 介助犬育成団体が主催しているイベントに行く

5）ネットや本から情報を得る

6) その他 (

\section{【児童生徒について】}

9. 担当しているクラスの児童生徒の数注何人ですか? ? ( ) 人

○。担当しているクラスの児童生徒の疾患として該当する番号に○をつけ、( ) に人数を記入してく

ださい。該当しない場合は、6）に疾患名と人数を記入してください。

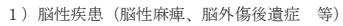

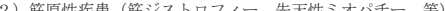

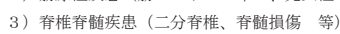

等

6) その他 (

1. 知的障害を合併している生徒はいますか? 1) の場合は（）に人数を記入してください。

1)はい 2) いいえ

12．児童生徒の自立や社会参加の一つの手段として、介助犬が有効であると考えますか?

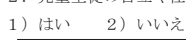

$$
\text { 理由 }
$$

3、生徒の自立や社会参加に向けてどのような授業や取り組みを行っていますか? 具体的に㧍答之 ください。

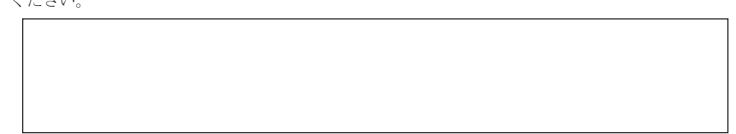

4、授業の中で、介助犬に関して取り上げたことはありますか?

1)はい2) いい之

１）と答えた方は、どのような授業を行いましたか?内容を具体的にお答えください。

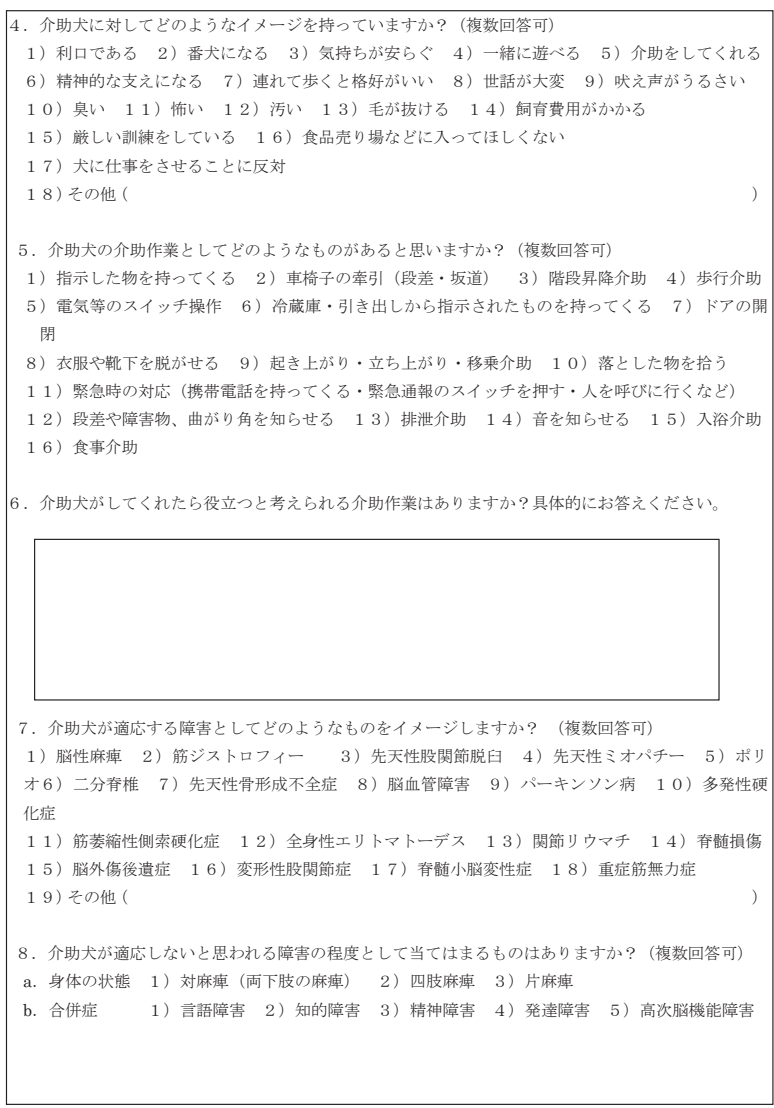

・2）と答えた方は、なぜ取り上げたことがないのですか？

1）介助犬自体を知らなかったから

2）担当している児童生徒には有効でないと思ったから

3）取り上け゚たいと思ったが、機会がなかったから

4) その他 (

15、今後、授業の中で介助犬を取り上げたいと思いま寸か?

1) はい 2) いい之

理

1）と答えた方は、どのような方法で介助犬を取り上げたいと思いますか?（複数回答可）

1）デモンストレーション（抒仕事紹介）を実際に見る

2）介助犬使用者の打話を闑く

3) 介助犬育成施設に見学に行<

4) 生徒自身に介助犬について調ぶさせる

5) 教員が知識を身に付け生徒治伝える

6) その他 (

※最後に、ご質問や要望、ご意見等がございましたらご自由にご記入下さい。

ーアンケートは以上です。排忙しい中ご協力して頂き、誠にありがとうございました。 


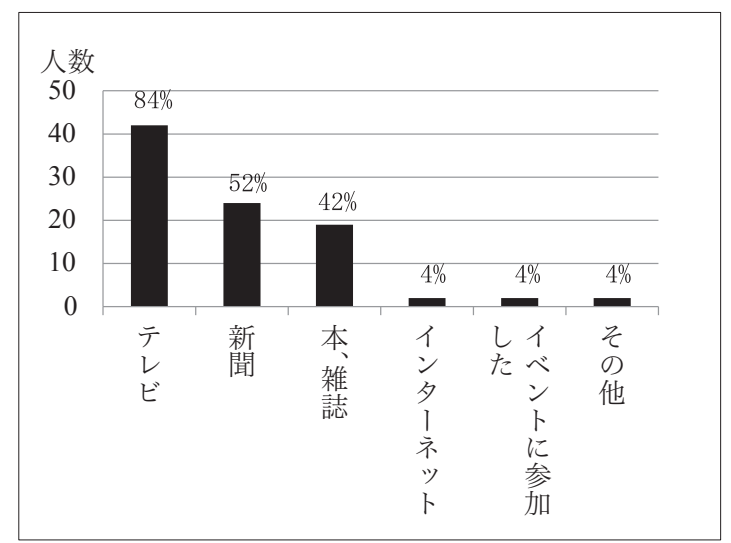

図 2 : 介助犬を知ったきっかけ

介助犬に対するイメージでは、「精神的な支えに なる」と「利口である」がそれぞれ8 割を超えプラ スのイメージが上位を占めた一方、半数の人は「厳 しい訓練をしている」というマイナスのイメージを 持っていることが明らかとなった（図３）。

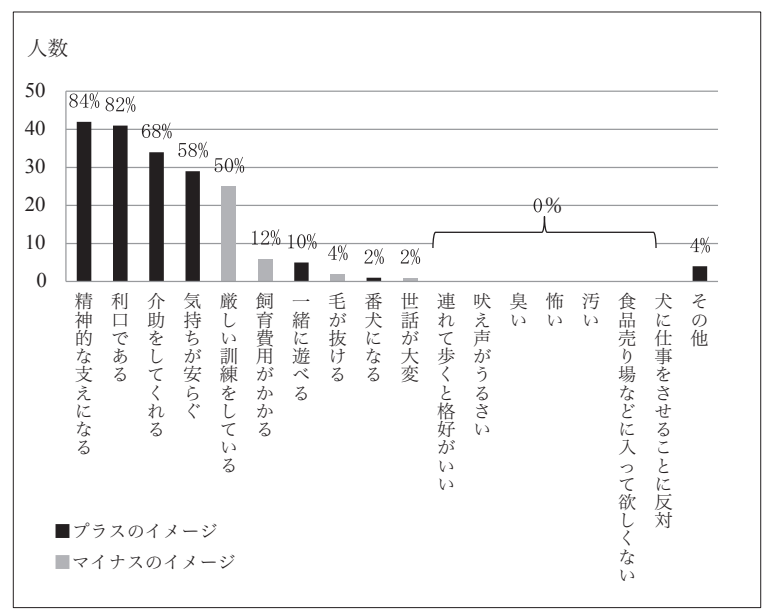

図 3 : 介助犬に対するイメージ（複数回答）

介助犬の作業を複数回答で尋㸚たところ、介助犬 の作業に加え、盲導犬・聴導犬の作業も同時に選択 するなど、介助犬の作業と盲導犬・聴導犬の作業と を混同している教員が54\%にも上った。

\section{3 . 介助犬の有効性}

生徒の疾患について、教員 50 名中 37 名から回答 を得た（有効回答率74\%)。担当している生徒全体 の 7 割を占める脳性疾患のうち、大半は知的障害や 言語障害などを合併することの多い脳性麻痺であ

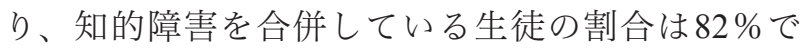
あった。このような生徒において、「介助犬が有効 であると考元るか」と聞いたところ、「いいえ」と 答えた $38 \%$ のうち、約 7 割が生徒の障害の程度や 状態を理由としており、その中でも最も多かったの がコミュニケーションの問題であった。しかし「い
いえ」と答えた方の中でも、「本人や家族が希望す れば」「もと詳しく知りたい」という意見もあった。

4. 介助犬への関心

これまでに「介助犬について授業で取り上げたこ とがある」と回答したのは $4 \%$ のみで、取り上げた ことのない理由としては「担当している生徒に有効 でないと思う」が40\%を占めた。また、「説明の方 法や内容がわからなかった」といた意見もあった。 さらに、「今後授業で取り上げたい」と答えた $26 \%$ （13名）にその理由を聞いたところ、「利用できる サービスをより多く知る必要がある」「有効な生徒 に出会ったら取り上げたい」といったものがあっ た。逆に、「取り上げたいと思わない」と答えた方 の理由としては、障害の程度や介助犬の知識不足が あげられた。しかしここでも、「生徒や保護者が求 めていれば一緒に取り組む」といった前向きな意見 があった。

また、全体の $68 \%$ が「介助犬についてより詳し く知りたい」と答えており、介助犬に対する関心の 高さが伺えた。介助犬の理解の促進の手段として は、「デモンストレーションを実際に見る」が $61 \%$ と最も多く、次いで「介助犬使用者の括を聞く」 39\%であった（図 4 )。

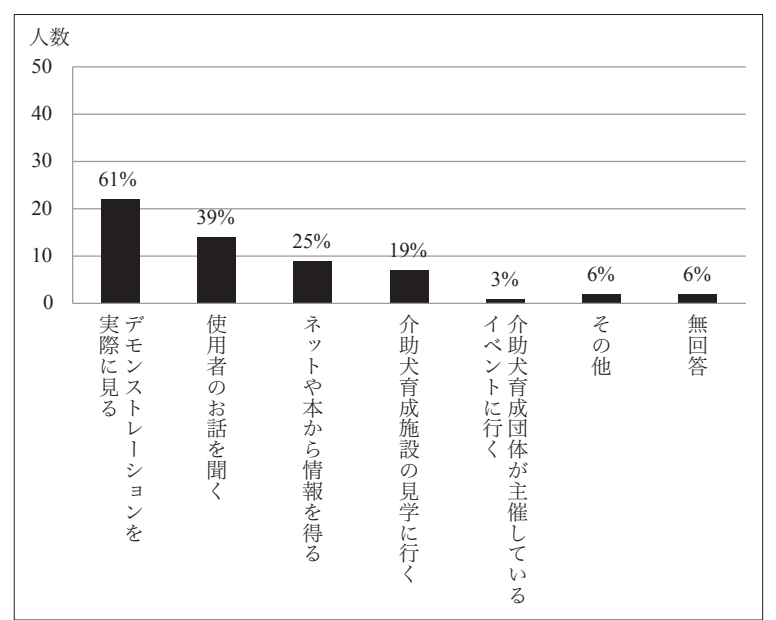

図 4 : 介助犬の理解促進の手段（複数回答）

さらに、「介助犬を授業で取り上げたい」と答え た $26 \%$ に授業で取り上げる際の手段の希望を聞い たところ、「介助の理解の促進の手段」と同様、「デ モンストレーションを見る」「使用者のお話を聞く」 が上位であった（図 5 )。 


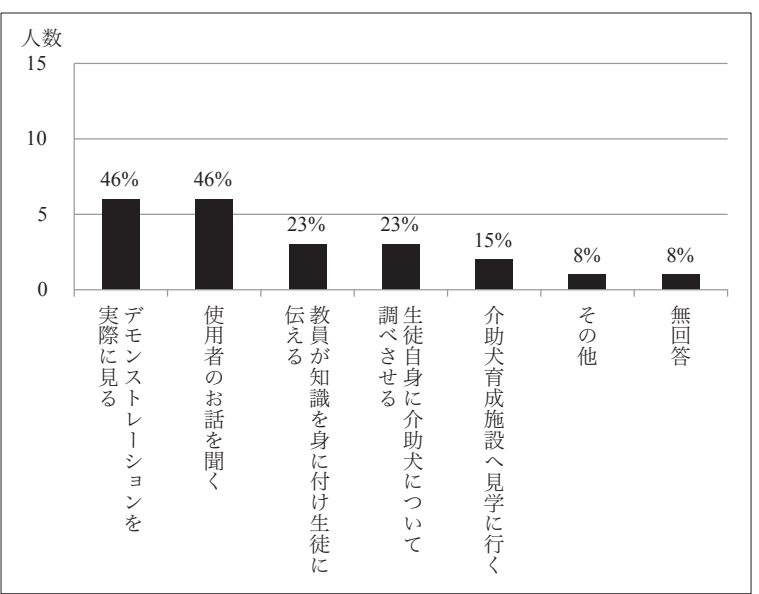

図 5：授業で取り上げる際の手段（複数回答）

\section{IV. 考察}

介助犬を必要とする障害者の疾患として、主に脊 髄損傷、多発性硬化症、神経筋疾患、筋疾患（筋ジ ストロフィー等)、神経難病（パーキンソン病、脊 髄小脳変性症)、筋委縮性側索硬化症等)、脳血管障 害等が挙げられる2)。

今回調査を行った特別支援学校（肢体不自由）に おいては、脳性疾患（脳性麻痺、脳外傷後遺症等） が $68 \%$ を占め、次いで筋原性疾患（筋ジストロ フィー、先天性ミオパチー等） $6 \%$ 、骨関節疾患 (先天性股関節脱臼等) $4 \%$ 、脊椎脊髄疾患（二分 春椎、春髄損傷等） $3 \%$ 、骨系統疾患（先天性骨形 成不全） $2 \%$ 、という結果となった。これは2000年 に行われた児童生徒病因別調査（全国肢体不自由養 護学校校長会編 $)^{6)}$ の割合とほぼ同様になっている。

脳性疾患の中でも大半を占める脳性麻痺は、運動 障害に加え言語障害や知的障害も伴うことが多く、 症例によりきめ細やかな対応によって介助犬の訓練 を行わなければならない2)。また、介助犬を貸与す るにあたっては、介助犬が本人にとって社会参加と 自立、社会復帰に寄与する手段であるかどうか、よ り有効性を見極めることが求められると予想され る。障害の程度やコミュニケーション手段の不足を 理由として「介助犬は有効でない」と考える教員が 約 4 割を占めた一方、介助犬についての関心は高 く、正しい知識を身に付けたいという意見も多く あった。このことから、特別支援学校（肢体不自 由）に拈いて介助犬が適応する生徒は限られるが、 教員に対して啓発の有効性があることが明らかと なった。

また、本調査により特別支援学校（肢体不自由）
の教員において、介助犬という言葉を「全く聞いた ことがない」と答えた回答者はおらず、介助犬の認 知度は高いことがわかった。しかし、盲導犬や聴導 犬の作業と介助犬の作業を混同している教員が約半 数、「厳しい訓練をしている」といったイメージを 半数近くの教員が持っているなど、介助犬に関して 正しい理解ができていないことが明らかとなった。 その原因としては、活動している介助犬が少なく遭 遇の機会が少ないこと、イベントなどの介助犬を知 ることのできる機会の不足、マスメディア以外の本 や雑誌、学校向けの資料などでの正しい情報提供の 不足などが考元られる。

今後の啓発方法として、より正しく介助犬を知っ て頂けるよう特別支援学校向けの資料作成・配布、 デモンストレーションや使用者の講演といった自分 で見たり聞いたりできる機会の提供が必要であると 考える。また、介助犬訓練センターのある愛知まで 足を運ぶことが難しい障害者もいるため、特別支援 学校に出向いての啓発活動等も必要であると考える。

今後、さらに他の特別支援学校（肢体不自由）で の調査を行い、地域ごとの認知度を比較検討する 他、障害の種類・程度割合から見た学校ごとの比較 検討を行い、特別支援学校向けの体験会等のイベン トも企画していきたい。

\section{V，謝辞}

本調査の主旨に同意頂き、アンケート実施にご協 力いただきました特別支援学校教員の皆様に心から 感謝申し上げます。

文献

1 ）厚生労働省ホームページ 平成 18 年「身体障 害児・者実態調査結果」http://www.mhlw.go.jp/ toukei/saikin/hw/shintai/06/index.html

2 ）高柳哲也編（2002）『介助犬を知る』名古屋大 学出版会

3 ) 厚生労働省ホームページ「補助犬別実働頭数 (H27.7.1 現在)」http://www.mhlw.go.jp/topics/ bukyoku/syakai/hojyoken/html/b04.html

4 ）大林博美，高柳友子，樋口恵子・他（1999）障 害者の自立生活を支援する介助犬の導入に関し て一外出頻度の高い障害者の介助への意識調査 一. 平成 11 年度厚生科学研究障害保健福祉総 合研究事業 介助犬の基礎的調査研究報告書, 27-35 
5 ) 文部科学省ホームページ「特別支援教育資料 (平成 18 年)」http://www.mext.go.jp/a_menu/shotou/ tokubetu/material/013.htm

6 ）全国特別支援 肢体不自由教育校長会ホーム ページ「児童生徒病因別調査」http://www. zentoku.jp/tokusyu/index.html 